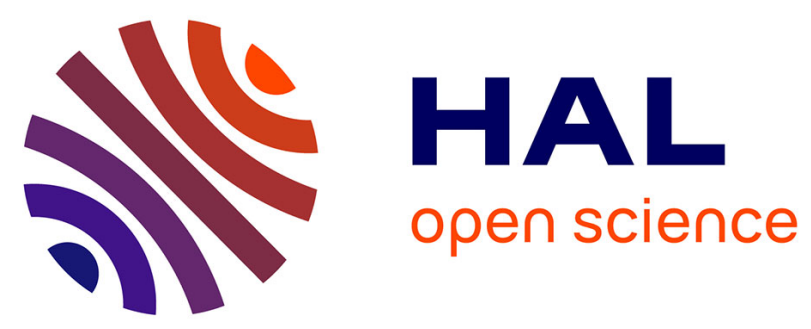

\title{
Analysis of twenty five impurities in uranium matrix by ICP-MS with iron measurement optimized by using reaction collision cell, cold plasma or medium resolution
}

Alexandre Quemet, Rene Brennetot, Emilie Chevalier, Edwina Prian, Anne-Laure Laridon, Clarisse Mariet, Pascal Fichet, Ivan Laszak, Florence Goutelard

\section{To cite this version:}

Alexandre Quemet, Rene Brennetot, Emilie Chevalier, Edwina Prian, Anne-Laure Laridon, et al.. Analysis of twenty five impurities in uranium matrix by ICP-MS with iron measurement optimized by using reaction collision cell, cold plasma or medium resolution. Talanta, 2012, 99, pp.207 - 212. 10.1016/j.talanta.2012.05.041 . cea-03470725

\section{HAL Id: cea-03470725 https://hal-cea.archives-ouvertes.fr/cea-03470725}

Submitted on 8 Dec 2021

HAL is a multi-disciplinary open access archive for the deposit and dissemination of scientific research documents, whether they are published or not. The documents may come from teaching and research institutions in France or abroad, or from public or private research centers.
L'archive ouverte pluridisciplinaire HAL, est destinée au dépôt et à la diffusion de documents scientifiques de niveau recherche, publiés ou non, émanant des établissements d'enseignement et de recherche français ou étrangers, des laboratoires publics ou privés. 


\title{
Analysis of twenty five impurities in uranium matrix by ICP-MS with iron measurement optimized by using reaction collision cell, cold plasma or medium resolution
}

\author{
Alexandre Quemet ${ }^{a}$, Rene Brennetot ${ }^{a}, *$, Emilie Chevalier ${ }^{a}$, Edwina Prian $^{a}$, Anne-Laure Laridon ${ }^{a}$, \\ Clarisse Mariet $^{\mathrm{b}}$, Pascal Fichet ${ }^{\mathrm{a}}$, Ivan Laszak ${ }^{\mathrm{b}}$, Florence Goutelard ${ }^{\mathrm{a}}$



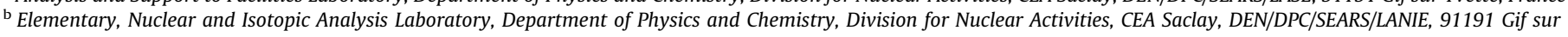 \\ Yvette, France
}

\section{A R T I C L E I N F O}

\section{Article history:}

Received 22 February 2012

Received in revised form

9 May 2012

Accepted 19 May 2012

Available online 1 June 2012

\section{Keywords:}

ICP-MS

Impurities

Uranium matrix

Dissolution

Separation

\begin{abstract}
A B S T R A C T
An analytical procedure was developed to determine the concentration of 25 impurities ( $\mathrm{Li}, \mathrm{Be}, \mathrm{Ti}, \mathrm{V}, \mathrm{Cr}$, $\mathrm{Mn}, \mathrm{Fe}, \mathrm{Co}, \mathrm{Ni}, \mathrm{Cu}, \mathrm{Zn}, \mathrm{Zr}, \mathrm{Mo}, \mathrm{Ag}, \mathrm{Cd}$, In, Sm, Eu, Gd, Dy, W, Pb, Bi and Th) in a uranium matrix using the quadrupole inductively coupled plasma mass spectrometry (Q-ICP-MS). The dissolution of $\mathrm{U}_{3} \mathrm{O}_{8}$ powder was made with a mixture of hydrochloric acid and nitric acid. Then, a selective separation of uranium using the UTEVA column was used before measurement by Q-ICP-MS. The procedure developed was verified using the Certified Reference Material "Morille". The analytical results agree well except for 5 elements where values are underestimated ( $\mathrm{Li}, \mathrm{Be}, \mathrm{In}, \mathrm{Pb}$ and $\mathrm{Bi}$ ). Among the list of impurities, iron was particularly investigated because it is well known that this element possesses a polyatomic interference that increases the detection limit. A comparison between iron detection limits obtained with different methods was performed. Iron polyatomic interference was at least reduced, or at best entirely resolved in some cases, by using the cold plasma or the collision/reaction cell with several gases ( $\mathrm{He}, \mathrm{NH}_{3}$ and $\mathrm{CH}_{4}$ ). High-resolution ICP-MS was used to compare the results obtained. A detection limit as low as $8 \mathrm{ng} \mathrm{L}^{-1}$ was achieved.
\end{abstract}

(c) 2012 Elsevier B.V. All rights reserved.

\section{Introduction}

The determination of trace $\left(\mathrm{mg} \mathrm{L}^{-1}\right)$ and ultra-trace levels ( $\mu \mathrm{g} \mathrm{L}^{-1}$ and $n g \mathrm{~L}^{-1}$ ) is very important for different applications such as: environmental, industrial, forensic, medical and nuclear. Impurities in uranium oxide are of prime interest for the International Atomic Energy Agency (IAEA) in the monitoring of nuclear installations to verify the material conformity to the nuclear grade specifications, to identify material origins, etc. [1-5].

Because uranium oxide samples are received in a solid form and are to be studied with Inductively Coupled Plasma (ICP), a dissolution procedure needed to be found. Various procedures are available to dissolve uranium oxide samples, such as: dissolution in acid mixture [6-9], oxidizing conditions [10,11], photochemical reaction [12], supercritical fluid carbon dioxide [13] and microwave dissolution $[14,15]$ can be used.

However, measurement of impurities at trace or ultra trace level in the presence of uranium at several $\mathrm{g} \mathrm{L}^{-1}$ levels is very challenging due to possible matrix effect affecting the accuracy of

\footnotetext{
* Corresponding author. Tel.: +331690856 23; fax: +33169085411.

E-mail address: rene.brennetot@cea.fr (R. Brennetot).
}

impurities concentration measurement. This is the reason why some separation methods have been developed in order to extract or eliminate the uranium matrix, among them: solvent extraction [16-18] or column extraction chromatography [19,20].

Several studies for impurities measurement in uranium matrix have been reported in literature. There are mainly two principal techniques used for this kind of measurement: Inductively Coupled Plasma-Atomic Emission Spectrometry [2,16,18,19] (ICP-AES) and Inductively Coupled Plasma-Mass Spectrometry [1,3,17,21] (ICPMS). Depending of the concentration level that has to be reached, either can be used to determine the concentration of interest. In the case of $\mu \mathrm{g} \mathrm{L}^{-1}$ and $n g \mathrm{~L}^{-1}$ level, ICP-MS is more appropriate.

ICP-MS became a versatile tool since it gives good detection limit for many elements with short time analysis. The main limitation is the presence of many interferences for $\mathrm{m} / \mathrm{z}$ below $80 \mathrm{amu}$. Isobaric interferences arise from elements having equal mass isotopes (for instance ${ }^{40} \mathrm{Ar}^{+} /{ }^{40} \mathrm{Ca}^{+}$) whereas polyatomic interferences are due to the combination of an element $\mathrm{M}$ or $\mathrm{Ar}$, from the gas used to generate the plasma, with sample or matrix ions like $\mathrm{C}^{+}, \mathrm{N}^{+}$and $\mathrm{O}^{+}$to form $\mathrm{MO}^{+}, \mathrm{ArC}^{+}, \mathrm{ArN}^{+}$and $\mathrm{ArO}^{+}$species.

There are several ways to suppress interferences. First, chemical separation can be used to resolve isobaric interferences: $[22,23]$ interfering elements are separated and mono-elemental 
purified fractions are obtained. An alternative way for multiisotopic elements is to use another isotope, free of interferences but it has to be compatible with the desired concentration level of the element. For a mono-isotopic element, an interference correction equation can be useful to resolve some interference $\left({ }^{35} \mathrm{Cl}^{16} \mathrm{O}^{+} /{ }^{51} \mathrm{~V}^{+}\right.$with the measurement of ${ }^{37} \mathrm{Cl}^{16} \mathrm{O}^{+}$at mass 53 for instance). Nevertheless, these methods cannot be used to resolve the interferences generated by the plasma.

One approach to reduce these polyatomic interferences is to use cold plasma operating conditions [24,25]. However, these conditions are not robust and a decrease of sensitivity is commonly observed. Moreover, it is limited to elements presenting a low ionization potential.

A similar decrease of sensitivity is observed with high resolution using a sector field ICP-MS (SF-ICP-MS), although it presents the ability to separate ions with very close $m / z$ ratios (typically, when a resolution lower than 10,000 is required) [26-28].

Recent studies have shown the great potential of collision/ reaction cells implanted in ICP-MS to perform direct isobaricpolyatomic interferences resolution [29-33]. This system is based on the addition of a collision and/or reaction gas after the ions extraction. Gas molecules collide or react with the ion beam and the interferences are eliminated or reduced. The choice of the gas is crucial and is based on the difference of behavior between the analyte and the interfering species [33].

Iron measurements by ICP-MS with a collision and/or reaction cell have been performed on various matrices and instruments. Gases such as $\mathrm{CH}_{4}, \mathrm{NH}_{3}, \mathrm{~N}_{2} \mathrm{O}, \mathrm{H}_{2}, \mathrm{H}_{2}$ in He have been tested to resolve the ${ }^{40} \mathrm{Ar}^{16} \mathrm{O}^{+} /{ }^{56} \mathrm{Fe}^{+}$interference and achieve the lowest detection limit [26,34-37].

Several mechanisms have been proposed to explain the reaction between the ions and the reaction gas molecules, among them: association or clustering reaction, atom transfer reaction and charge transfer reaction [33]. For example, when $\mathrm{ArO}^{+}$reacts with $\mathrm{H}_{2}$, the species $\mathrm{ArOH}^{+}$and $\mathrm{H}_{2} \mathrm{O}^{+}$are observed because of an hydrogen transfer reaction and an association reaction, respectively. Meanwhile, $\mathrm{Fe}^{+}$ions are not impacted by $\mathrm{H}_{2}$ and can be analyzed at mass $56[34,38,39]$. Conversely, $\mathrm{N}_{2} \mathrm{O}$ reacts with $\mathrm{Fe}^{+}$ to form $\mathrm{FeO}^{+}$by means of an oxygen transfer reaction: iron measurement is performed at the corresponding mass of 72 $[34,39]$. On the other hand, due to their low energy potential, $\mathrm{NH}_{3}$ and $\mathrm{CH}_{4}$ can react with $\mathrm{ArO}^{+}$by a charge transfer mechanism whereas $\mathrm{Fe}^{+}$ions are not impacted $[40,41]$. Alternatively, the low dissociation energy of the $\mathrm{Ar}-\mathrm{O}$ bound $(0.31 \mathrm{eV})$ [42] could be broken by collision with the use of an inert gas, for instance He.

After a brief description of the microwave dissolution and separation procedure on a UTEVA resin, the results obtained for measurement of 25 impurities in the Certified Reference Material (CRM) Morille (CETAMA, France) will be discussed in terms of limit of detection and \% of recovery.

A particular focus will then be done for iron measurement in $2 \mathrm{M}$ $\mathrm{HNO}_{3}$ solution. On the one hand, the resolution of the $\mathrm{Fe}^{+} / \mathrm{ArO}^{+}$ interference by using the collision/reaction cell in the Q-ICP-MS was studied with three different gases to determine the detection limit (He as collision gas and $\mathrm{NH}_{3}$ and $\mathrm{CH}_{4}$ as reaction gases). On the other hand, we use the medium resolution of a sector field ICP-MS to resolve the interference. For each instrument, a comparison between standard and cold plasma conditions was performed.

\section{Experimental}

\subsection{Materials and reagents}

A microwave-assisted reaction system furnace (Speedwave, Berghof, Germany) with Teflon (PTFE) vessels was used for the dissolution of the CRM at $1300 \mathrm{~W}$ with $2.45 \mathrm{GHz}$ microwave field. The solution temperature in the vessel was automatically controlled with an infrared sensor regulating the power output. Likewise, the pressure inside each vessel was measured to avoid any build-up.

UTEVA resin (Triskem, France) with $100-150 \mu \mathrm{m}$ particle size in $2 \mathrm{~mL}$ prepackaged columns was used for the separation procedure in order to fix the uranium matrix.

An Agilent Technologies 7700x Q-ICP-MS was used for this study, together with a Thermo Fischer Scientific Element 2 SF-ICPMS to compare the detection limits of iron (in medium resolution, near 4000). The SF-ICP-MS has three nominal resolutions $(R=M /$ $\Delta M$ at $10 \%$ peak height) settings: low (LR: $R=300$ ), medium (MR: $R=4000$ ), and high (HR: $R=9000$ ). For this method we configure the mass spectrometer to perform in MR.

The main operating parameters are summarized in Table 1. First, in standard mode with the 7700x ICP-MS (i.e. without gas in the collision/reaction cell) sensitivity maximization and short term stability tests were performed on a daily test using a $1 \mu \mathrm{g} \mathrm{L}^{-1}$ solution of $\mathrm{U}$ and In. Typical sensitivities were better than 150,000 counts $\mathrm{s}^{-1}\left(\mu \mathrm{g} \mathrm{L}^{-1}\right)^{-1}$ with a residual standard deviation better than $1 \%$ for 10 measurements of $1 \mathrm{~min}$. Under such optimum conditions, the formation levels of the oxide ions $\left({ }^{140} \mathrm{Ce}^{16} \mathrm{O}^{+} /{ }^{140} \mathrm{Ce}^{+}\right)$and of the double charge ions $\left({ }^{138} \mathrm{Ba}^{++} /\right.$ ${ }^{138} \mathrm{Ba}^{+}$) were found to be lower than $2 \%$ and $3 \%$ respectively. Then, in gas mode, a blank solution (the acid of preparation) was used to optimize the gas flow rate and the instrumental parameters in order to reduce the $\mathrm{ArO}^{+}$interference. A $1 \mu \mathrm{g} \mathrm{L}^{-1}$ indium solution, presenting no gas reaction, was used to maximize sensitivity for each collision/reaction gas flow rate.

High purity standards were used for the preparation of the external calibration curves. They were prepared from single element SPEX (SPEX Certiprep, France) solutions (1000 $\mathrm{mg} \mathrm{L}^{-1}$ ) diluted in a $2 \mathrm{M}$ nitric acid solution. This $2 \mathrm{M}$ nitric acid solution was prepared by diluting a sub-boiling $15 \mathrm{M}$ nitric acid solution with deionized water (resistivity $18.2 \mathrm{M} \Omega . \mathrm{cm}$ ). Sub-boiling nitric

Table 1

Typical ICP-MS operating conditions. Gas flow rate are in $\mathrm{L} \mathrm{min}^{-1}$ and plasma power is in $\mathrm{W}$.

\begin{tabular}{|c|c|c|}
\hline & 7700x Agilent & Element 2 Thermo Fisher \\
\hline Plasma power & 1550 & 1200 \\
\hline Cooling gas flow rate & 15 & 16 \\
\hline Auxiliary gas flow rate & 0.90 & 0.80 \\
\hline Nebulizer gas flow rate & 1.05 & 1.20 \\
\hline Nebulizer & Quartz concentric & Quartz concentric \\
\hline Spray chamber & Scott chamber & Scott chamber \\
\hline Torch shield & Yes & Yes \\
\hline Cell geometry & Octopole & - \\
\hline Standard mode & - & - \\
\hline Octopole bias & -8 & \\
\hline Quadrupole bias & -3 & \\
\hline He mode & - & - \\
\hline Octopole bias & -18 & \\
\hline Quadrupole bias & -15 & \\
\hline Gas flow rate & 6.1 & \\
\hline He high energy mode & - & - \\
\hline Octopole bias & -100 & \\
\hline Quadrupole bias & -86 & \\
\hline Gas flow rate & 10 & \\
\hline $\mathrm{CH} 4$ mode & - & - \\
\hline Octopole bias & -18 & \\
\hline Quadrupole bias & -15 & \\
\hline Gas flow rate & 1.4 & \\
\hline NH3 mode & - & - \\
\hline Octopole bias & -18 & \\
\hline Quadrupole bias & -15 & \\
\hline Gas flow rate & 1.4 & \\
\hline
\end{tabular}

- Not applicable. 
acid solution was achieved by distillation of a $65 \% \mathrm{HNO}_{3}$ Normatom solution (Prolabo, France) using an EVAPOCLEAN system (Analab, France). $12 \mathrm{M}$ sub-boiling hydrochloric was achieved by distillation of a $35 \% \mathrm{HCl}$ Ultrex solution (Fischer Scientific, France) and was used for the dissolution. A 45\% HF Ultrex solution (Fischer Scientific, France) was used for the separation process. ${ }^{45} \mathrm{Sc}\left(5 \mu \mathrm{g} \mathrm{L}^{-1}\right),{ }^{139} \mathrm{La}(1 \mu \mathrm{g} \mathrm{L}-1)$ and ${ }^{205} \mathrm{Tl}\left(1 \mu \mathrm{g} \mathrm{L}{ }^{-1}\right)$ are used as internal standard for ICP-MS measurements. Dilutions were performed gravimetrically with high precision balance.

The assessment of the procedure investigated was carried out on a CRM "Morille" provided by the CETAMA. It consists in a $\mathrm{U}_{3} \mathrm{O}_{8}$ powder to which 25 elements concentration is certified.

High purity of helium (99.9999\% purity), methane $(99.9995 \%$ purity) and ammonia (99.98\% purity) were used as collision or reaction gases in the cell of the ICP-MS (Messer, France).

\subsection{Dissolution procedure}

Dissolution procedure includes the cleaning of all the vessels used to prepare dissolution. The same acids were used for cleaning and dissolution. The CRM was dried at $110{ }^{\circ} \mathrm{C}$ for at least $3 \mathrm{~h}$ in a drying oven, prior to any sampling. $0.6 \mathrm{~g}$ of $\mathrm{U}_{3} \mathrm{O}_{8}$ was precisely weighted before the digestion process. Dissolution program begins with a temperature ramp of $1{ }^{\circ} \mathrm{C} / \mathrm{min}$ and a first stage of $5 \mathrm{~min}$ at $90{ }^{\circ} \mathrm{C}$. A second ramp is then performed to reach $110{ }^{\circ} \mathrm{C}$ during $30 \mathrm{~min}$. $15 \mathrm{~mL}$ of $8 \mathrm{~N}$ hydrochloric acid and $6 \mathrm{~N}$ nitric acid $(50 / 50 \mathrm{v} / \mathrm{v})$ both of sub-boiling quality was used to perform dissolution of the CRM. This acid mixture was chosen to ensure a maximum stability of the elements of interest in the dissolution solution and to ensure a complete dissolution of the sample.

\subsection{Separation procedure}

UTEVA column was first conditioned and then by washing the column with $20 \mathrm{~mL}$ of deionised water (resistivity $18.2 \mathrm{M} \Omega . \mathrm{cm}$ ) and $10 \mathrm{~mL}$ of $\mathrm{HNO}_{3} 3 \mathrm{M}$, and then equilibrated with $20 \mathrm{~mL}$ of the $\mathrm{HNO}_{3} / \mathrm{HF}(8 \mathrm{M} / 0.1 \mathrm{M})$ acid mixture used for the separation. The conditioning was optimized to ensure that the separation blanks were as low as possible for all the element of interest. The solution obtained after dissolution with the microwave furnace was weighed and evaporated to dryness. Sample was deposited on the column with $3 \times 200 \mu \mathrm{L}$ of the $\mathrm{HNO}_{3} / \mathrm{HF}$ acid mixture and the elution was performed with $10 \mathrm{~mL}$ of the acid mixture. The solution obtained after separation is purified in uranium and the uranium decontamination was checked by ICP-MS measurement. As a result, up to $99.997 \%$ uranium was eliminated. All impurity measurements, which were in $10 \mathrm{~mL}$ of the acid mixture, were performed using a diluted acid (typically by a factor of 4 ) to be more suitable with the ICP-MS. This procedure was optimized to ensure a maximum recovery for $\mathrm{Zr}$ and $\mathrm{Th}$.

\section{Results and discussion}

\subsection{Estimation of the analytical measurement}

The limits of detection (Table 2) were estimated from the linear calibration curves (correlation coefficient $>0.999$ ) in the range tested (0.010-7 $\left.\mu \mathrm{g} \mathrm{L}^{-1}\right)$ and were expressed in amount of the element in the $\mathrm{U}_{3} \mathrm{O}_{8}$ material. The limit of detection was calculated according to the IUPAC ( 3 standard deviation of blank signal/slope). These values gave an indication of the reachable performance. They did not include the matrix effect as they were obtained with a $2 \mathrm{M} \mathrm{HNO}_{3}$ matrix, nor the separation yield as they were calculated considering a yield of $100 \%$.
Table 2

Detection limits in the solid (LD (CRM)) in $\mu \mathrm{g} \mathrm{kg}^{-1} \mathrm{U}$, and experimental results ( $\mathrm{mg} \mathrm{kg}^{-1} \mathrm{U}$ ) of the Certified Reference Material "Morille" by Agilent 7700x Q-ICPMS and Thermo Fischer Element 2 SF-ICP-MS

\begin{tabular}{lllll}
\hline Element & $\begin{array}{l}\text { Certified } \\
\mathrm{mg} \mathrm{kg}^{-1} \mathrm{U}\end{array}$ & $\begin{array}{l}\text { Measured } \\
\mathrm{mg} \mathrm{kg}^{-1} \mathrm{U}\end{array}$ & Recovery \% & $\frac{\mathrm{LD}(\mathrm{CRM}) \mu \mathrm{g} \mathrm{kg}{ }^{1} \mathrm{U}}{\text { Without U With } U}$
\end{tabular}

\begin{tabular}{|c|c|c|c|c|c|}
\hline \multicolumn{6}{|c|}{ Agilent 7700x Q-ICP-MS } \\
\hline $\mathrm{Li}$ & $5.0 \pm 0.2$ & $3.8 \pm 0.2$ & $76 \pm 5$ & 9 & - \\
\hline $\mathrm{Be}$ & $5.4 \pm 0.6$ & $4.0 \pm 0.2$ & $76 \pm 5$ & 4 & - \\
\hline $\mathrm{Ti}$ & $49.2 \pm 2.6$ & $45.5 \pm 2.4$ & $92 \pm 5$ & 65 & 155 \\
\hline $\mathrm{V}$ & $48.7 \pm 2.8$ & $41.8 \pm 2.2$ & $86 \pm 5$ & 2 & 12 \\
\hline $\mathrm{Cr}$ & $99 \pm 2$ & $95 \pm 6$ & $96 \pm 6$ & 17 & 62 \\
\hline Mn & $24.5 \pm 0.5$ & $24.4 \pm 1.6$ & $100 \pm 6$ & 9 & 25 \\
\hline $\mathrm{Fe}$ & $211.6 \pm 6.5$ & $189.1 \pm 23.0$ & $89 \pm 12$ & 52 & 205 \\
\hline Co & $9.8 \pm 2.0$ & $9.4 \pm 0.8$ & $96 \pm 9$ & 2 & 4 \\
\hline $\mathrm{Ni}$ & $147 \pm 3$ & $144 \pm 5$ & $98 \pm 4$ & 34 & 62 \\
\hline $\mathrm{Cu}$ & $50.2 \pm 1.0$ & $47.7 \pm 2.0$ & $95 \pm 4$ & 9 & 75 \\
\hline $\mathrm{Zn}$ & $98.6 \pm 5.5$ & $97.7 \pm 9.0$ & $97 \pm 7$ & 4 & 124 \\
\hline $\mathrm{Zr}$ & $59.9 \pm 4.1$ & $64.1 \pm 1.2$ & $107 \pm 7$ & 90 & - \\
\hline Mo & $147 \pm 5$ & $136 \pm 17$ & $93 \pm 13$ & 9 & 6 \\
\hline $\mathrm{Ag}$ & $10.4 \pm 1.6$ & $11.7 \pm 1.0$ & $112 \pm 9$ & 1 & - \\
\hline $\mathrm{Cd}$ & $4.9 \pm 0.7$ & $4.9 \pm 0.2$ & $100 \pm 3$ & 2 & 12 \\
\hline In & $9.4 \pm 1.0$ & $7.5 \pm 0.4$ & $80 \pm 5$ & 1 & 2 \\
\hline Sn & $18.5 \pm 5.6$ & $16.5 \pm 2.2$ & $89 \pm 14$ & 13 & 633 \\
\hline Sm & $0.50 \pm 0.12$ & $0.51 \pm 0.02$ & $102 \pm 2$ & 1 & 3 \\
\hline Eu & $0.52 \pm 0.03$ & $0.52 \pm 0.02$ & $100 \pm 2$ & 1 & 1 \\
\hline $\mathrm{Gd}$ & $0.56 \pm 0.06$ & $0.58 \pm 0.02$ & $103 \pm 2$ & 2 & 19 \\
\hline Dy & $0.50 \pm 0.06$ & $0.46 \pm 0.02$ & $92 \pm 4$ & 1 & 1 \\
\hline W & $100 \pm 9$ & $89 \pm 4$ & $90 \pm 2$ & 2 & 2 \\
\hline $\mathrm{Pb}$ & $101 \pm 3$ & $86 \pm 5$ & $89 \pm 4$ & 4 & 2 \\
\hline $\mathrm{Bi}$ & $24.4 \pm 1.9$ & $19.9 \pm 1.0$ & $81 \pm 5$ & 1 & 1 \\
\hline Th & $6.2 \pm 0.8$ & $6.4 \pm 0.2$ & $103 \pm 2$ & 1 & 3 \\
\hline \multicolumn{6}{|c|}{ Thermo Fischer Element 2 SF-ICP-MS } \\
\hline $\mathrm{Fe}$ & $211.6 \pm 6.5$ & $207.4 \pm 13.6$ & $98 \pm 3$ & 34 & - \\
\hline
\end{tabular}

- not determined.

The limits of detection were also estimated from the linear calibration curves, by using the matrix matching method, using an uranium matrix around $0.1 \mathrm{~g} \mathrm{~L}^{-1}$ (corresponding to a sample dilution of 100 after the dissolution). They were also expressed in amount of the element in the $\mathrm{U}_{3} \mathrm{O}_{8}$ material. The limits of detection of $\mathrm{Li}, \mathrm{Be}, \mathrm{Zr}$ and $\mathrm{Ag}$ were not determined by the matrix matching method.

The separation procedure allowed to decrease the uranium content by a 30,000 factor and therefore, the matrix effect. As a matter of fact, detection limits were improved by a 5-50 factor for the following elements: $\mathrm{V}, \mathrm{Cu}, \mathrm{Cd}, \mathrm{Sn}, \mathrm{Gd}$ and $\mathrm{Th}$, and slightly less than a 5 factor for all the other elements. It confirmed that the elimination of the uranium matrix allows for a lower level quantification, but that it is correlated to the nature of each element. The matrix separation prevents a pollution of the ICP also used to investigate trace uranium measurement in other research programs. It also increases the productivity by avoiding a complete wash of the instrument during a few days.

\subsection{Procedure check for the quantification of impurities in uranium matrix}

The procedure developed was assessed using the CRM "Morille" (CETAMA, France). Once the separation process was realized, a standard external calibration was used to determine the concentration of the following trace elements: $\mathrm{Li}, \mathrm{Be}, \mathrm{Ti}, \mathrm{V}, \mathrm{Cr}, \mathrm{Mn}, \mathrm{Fe}$, $\mathrm{Co}, \mathrm{Ni}, \mathrm{Cu}, \mathrm{Zn}, \mathrm{Zr}, \mathrm{Mo}, \mathrm{Ag}$, Cd, In, Sn, Sm, Eu, Gd, Dy, W, Pb, Bi and $\mathrm{Th}$. All the impurities were in the $\mathrm{mg} \mathrm{kg}^{-1} \mathrm{U}$ concentration range, matching perfectly the operational key use of the Q-ICP-MS. A quality check control at $1 \mu \mathrm{g} \mathrm{L}^{-1}$ and a blank solution, prepared in $\mathrm{HNO}_{3}$, were run before and after the sample in order to control 
the calibration curve and the pollution of the instrument. The results obtained are listed in Table 2 together with the quantitative recoveries. Each measured value is the average of 8 different separations on the same dissolution. The uncertainties values are given at $k=2$. The dissolution procedure was previously validated from 4 dissolutions of the CRM.

As shown, the analysis results agree satisfactorily with 19 of 25 certified values, whereas they are slightly underestimated (around $20 \%$ ) for $\mathrm{Li}, \mathrm{Be}, \mathrm{In}, \mathrm{V}, \mathrm{Pb}$ and $\mathrm{Bi}$.

When agreement was achieved with the certified value, recoveries are between $89 \pm 12 \%$ and $112 \pm 9 \%$. For the six other elements, recoveries are between $76 \pm 5 \%$ and $89 \pm 4 \%$. Nonetheless, some elution tests were performed to improve their separation and recoveries about $90 \%$ were completed for V, In, $\mathrm{Pd}$ and $\mathrm{Bi}$. Improvement on the separation of $\mathrm{Li}$ and $\mathrm{Be}$ are currently under investigation.

The repeatability was calculated for each element in order to estimate the quality of our analytical results: it was systematically below $6 \%$, thus demonstrating the validity of our analytical procedure.

\subsection{Study of the possibilities of the elimination of ${ }^{56} \mathrm{Fe}^{+} /{ }^{40} \mathrm{Ar}^{16} \mathrm{O}^{+}$ isobaric interferences}

Among all impurities, iron is the only one presenting a polyatomic interference that deteriorates the detection limit. Other elements, with potentially overlapped by polyatomic interferences $\left({ }^{7} \mathrm{Li}^{+} /{ }^{14} \mathrm{~N}^{++},{ }^{51} \mathrm{~V}^{+} /{ }^{38} \mathrm{Ar}^{13} \mathrm{C}^{+},{ }^{52} \mathrm{Cr}^{+} /{ }^{40} \mathrm{Ar}^{12} \mathrm{C}^{+},{ }^{53} \mathrm{Cr}^{+} /{ }^{40} \mathrm{Ar}\right.$ ${ }^{13} \mathrm{C}^{+},{ }^{59} \mathrm{Co}^{+} /{ }^{35} \mathrm{Cl}^{24} \mathrm{Mg}^{+} /{ }^{40} \mathrm{Ar}^{19} \mathrm{~F}^{+}$, etc.), have their limits of detection sufficiently low to allow their measures in the CRM without interferences resolution. The possibility to measure iron by ICPMS at a concentration level compatible with the CRM was assessed: its analytical performance was evaluated in terms of detection limit, background intensity, sensitivity and measurement error. All calibration curves were made in $\mathrm{HNO}_{3}$ with twelve calibration points in the $0-2 \mu \mathrm{g} \mathrm{L}^{-1}$ range. Two quality check controls (at 0.5 and $1 \mu \mathrm{g} \mathrm{L}^{-1}$ ), prepared independently in $\mathrm{HNO}_{3}$, were run with the samples in order to control drift and precision. Two different ICP-MS were used to evaluate the detection limit of iron: a Q-ICP-MS and a sector field ICP-MS. To estimate the iron detection limits three different conditions of ICP-MS were tested: the standard mode and the cold plasma conditions for the two ICP-MS (Q-ICP-MS and SF-ICP-MS), the use of the collision/ reaction cell for the Q-ICP-MS and the medium resolution for the SF-ICP-MS. The results are presented in Table 3.

\subsubsection{Standard mode}

In the standard mode, the iron measurement by Q-ICP-MS was made at mass 57 because the ${ }^{40} \mathrm{Ar}^{16} \mathrm{O}^{+}$intensity was higher than $4,000,000 \mathrm{cps}$ in the blank at mass 56 , and chromium interfere at mass 54. The detection limit at mass 57 was determined at $215 \mathrm{ng} \mathrm{L}^{-1}$.

The iron measurement by a SF-ICP-MS was made also at mass 57 using the low resolution. An improvement of the detection limit was achieved with a value of $44 \mathrm{ng} \mathrm{L}^{-1}$ confirming the better sensitivity of the SF-ICP-MS over the Q-ICP-MS.

The measurement errors were determined between 2 and $10 \%$ for the two quality check controls for the Q-ICP-MS and the SFICP-MS. The limit of detection of the Q-ICP-MS is close to the concentration of the two quality check controls explaining the high measurement errors, similar for both instruments.

\subsubsection{Cold plasma operating conditions}

One approach to overcome the ${ }^{40} \mathrm{Ar}^{16} \mathrm{O}^{+} /{ }^{56} \mathrm{Fe}^{+}$interference is to reduce the plasma power to reach the cold plasma conditions [43].
Table 3

Detection limits (LD) in $\mathrm{ng} \mathrm{L}^{-1}$ of iron in $\mathrm{HNO}_{3}$ and the measurement error (\%Bias) for the Agilent 7700x Q-ICP-MS and the Thermo Fischer Element 2 SF-ICP-MS and for different configurations instruments. Level 1 and 2 are the quality check control at 0.5 and $1 \mu \mathrm{g} \mathrm{L}^{-1}$, respectively.

\begin{tabular}{|c|c|c|c|}
\hline \multirow[t]{2}{*}{ Analysis condition } & \multirow[t]{2}{*}{$\mathrm{LD}\left(\mathrm{ng} \mathrm{L}^{-1}\right)$} & \multicolumn{2}{|c|}{ Quality check control } \\
\hline & & Level & $\%$ error \\
\hline \multicolumn{4}{|c|}{ Agilent 7700x Q-ICP-MS } \\
\hline \multirow[t]{2}{*}{ Standard $\left({ }^{57} \mathrm{Fe}\right)$} & 215 & 1 & 8 \\
\hline & & 2 & 2 \\
\hline \multirow[t]{2}{*}{ Cold plasma } & 15 & 1 & 9 \\
\hline & & 2 & 3 \\
\hline \multirow[t]{2}{*}{ He high energy mode } & 22 & 1 & 2 \\
\hline & & 2 & 3 \\
\hline \multirow[t]{2}{*}{$\mathrm{He}$} & 12 & 1 & 5 \\
\hline & & 2 & 1 \\
\hline \multirow[t]{2}{*}{$\mathrm{CH}_{4}$} & 8 & 1 & 2 \\
\hline & & 2 & 1 \\
\hline \multirow[t]{2}{*}{$\mathrm{NH}_{3}$} & 74 & 1 & 6 \\
\hline & & 2 & 5 \\
\hline \multicolumn{4}{|c|}{ Thermo Fischer Element 2 SF-ICP-MS } \\
\hline \multirow[t]{2}{*}{ Standard $\left({ }^{57} \mathrm{Fe}\right)$} & 44 & 1 & 3 \\
\hline & & 2 & 10 \\
\hline \multirow[t]{2}{*}{ Cold plasma } & 132 & 1 & 9 \\
\hline & & 2 & 22 \\
\hline \multirow[t]{2}{*}{ Medium resolution } & 10 & 1 & 4 \\
\hline & & 2 & 4 \\
\hline
\end{tabular}

Hence, analyte can be easily detected since the background caused by argon species is reduced. In the present study, the plasma power was reduced to $600 \mathrm{~W}$ for the Q-ICP-MS. Within these conditions, a $15 \mathrm{ng} \mathrm{L}^{-1}$ detection limit was obtained at mass 56 which is significantly lower than the ones obtained at mass 57 in the standard mode and in close agreement with the value of Huang and Lin (16 $\mathrm{ng} \mathrm{L}^{-1}$ ) [43]. The measurement errors for the Q-ICP-MS were higher for the first quality check control (9\%) and acceptable for the second one (less than $3 \%$ ).

On the other hand, when the plasma power was reduced to $700 \mathrm{~W}$ for the SF-ICP-MS, the detection limit was deteriorated to $132 \mathrm{ng} \mathrm{L}^{-1}$ compared to the $44 \mathrm{ng} \mathrm{L}^{-1}$ in the standard mode. The loss of sensitivity can explain the deterioration of the detection limit. However this type of set-up is not suitable for this apparatus when medium resolution can be used to make the measurement in good conditions.

For the SF-ICP-MS, the measurement errors were higher (more than $9 \%$ ) and are incompatible with the measurement of iron at low level.

\subsubsection{Medium resolution}

In theory, a 2500 resolution is required to separate ${ }^{40} \mathrm{Ar}^{16} \mathrm{O}^{+}$ from ${ }^{56} \mathrm{Fe}^{+}$and can be reached using the medium resolution of the SF-ICP-MS. Indeed, a detection limit of $10 \mathrm{ng} \mathrm{L}^{-1}$ was achieved which is of the same order of magnitude than the one obtained with the collision/reaction cell ICP-MS. The measurement errors were less than $4 \%$ for the two quality check controls, showing that it is the best way to measure iron with a SF-ICP-MS.

\subsubsection{Collision/reaction cell}

Different gases were tested to try to overcome the ${ }^{40} \mathrm{Ar}^{16} \mathrm{O}^{+}$ interference on ${ }^{56} \mathrm{Fe}^{+}$in order to improve the detection limit in $\mathrm{HNO}_{3}$ solution and also for trace analysis in uranium: $\mathrm{CH}_{4}$ [26], $\mathrm{NH}_{3}[34,36]$ and $\mathrm{He}[44]$.

Using the gas mode, the $\mathrm{ArO}^{+}$intensity was decreased by more than $99.95 \%$ and was lowered below $1000 \mathrm{cps}$.

The use of $\mathrm{He}$ as a collision gas, or $\mathrm{CH}_{4}$ as a reaction gas provided the best detection limits. With these two gases, a 
$10 \mathrm{ng} \mathrm{L}^{-1}$ detection limit was obtained at mass 56 , which is considerably lower than the one obtained at mass 57 in standard mode ( $215 \mathrm{ng} \mathrm{L}^{-1}$ ). This illustrates the capacity of the gas mode to eliminate interferences and to lower the limit of detection.

However, $\mathrm{NH}_{3}$ was not suitable to decrease lower the detection limit ( $74 \mathrm{ng} \mathrm{L}^{-1}$ ), value in the same order of magnitude than the one of Iglesias et al. (24 ng L ${ }^{-1}$ ) [34]. As $\mathrm{CH}_{4}$ and $\mathrm{NH}_{3}$ have close masses (16 and $17 \mathrm{~g} \mathrm{~mol} \mathrm{~L}^{-1}$ ) and react with the same mechanism, we could have expected to obtain very similar detection limits of iron. A decrease by a factor 2 of the iron intensity was observed using $\mathrm{NH}_{3}$. Beside, Koyanagi et al. [39] observed $\mathrm{FeNH}_{3}^{+}$and $\mathrm{FeCH}_{4}^{+}$species. However, one explanation could be that the formation of $\mathrm{FeNH}_{3}^{+}$has a reaction efficiency 20 times higher than the formation of the $\mathrm{FeCH}_{4}^{+}$species $[39,45]$. Furthermore, the formation of $\mathrm{FeNH}_{3}^{+}$is 4 times more exothermic than $\mathrm{FeCH}_{4}^{+}$, and the $\mathrm{Fe}-\mathrm{N}$ bonding energy is more than 4 times stronger than $\mathrm{Fe}-\mathrm{C}$. Even if the $\mathrm{FeNH}_{3}^{+}$and $\mathrm{FeCH}_{4}^{+}$species were not observed in the present study (lack of sensitivity), it is very likely that the $\mathrm{FeNH}_{3}^{+}$species was formed as a secondary reaction and hindered the analysis.

The 7700x (Q-ICP-MS) integrates also a high energy mode. The potential applied to the collision/reaction cell was fixed at a higher negative value $(-100 \mathrm{~V})$ and a higher helium gas flow rate was applied. These new conditions gave an ion energy around $100 \mathrm{eV}$ and allowed for a greater dissociation of $\mathrm{ArO}^{+}$by collision with helium. However, the detection limit of iron was slightly decreased ( $22 \mathrm{ng} \mathrm{L}^{-1}$ ) due to a reduction of the iron intensity.

The iron interference was properly reduced, leading to the accurate measurement of ${ }^{56} \mathrm{Fe}^{+}$with measurement errors better than $6 \%$ for the two quality check controls. These errors are the lowest compare to the values obtained with the standard method and the cold plasma condition, showing that the use of the collision reaction cell is the most suitable to measure iron with Q-ICP-MS.

\subsection{Implementation to iron measurement in the CRM Morille}

For the measurement of iron in CRM "Morille", we chose to measure iron with $\mathrm{He}$, even if $\mathrm{CH}_{4}$ slightly improved the detection limit. Indeed, we observed that $\mathrm{Mn}$, present as an impurity, weakly reacts with $\mathrm{CH}_{4}$ to form $\mathrm{MnH}^{+}$at mass 56 and interfere with the iron analysis. Therefore, using gas to improve sensitivity must be study in terms of sensitivity but also in terms of new interferences that can be formed with other impurities.

In the medium resolution of the SF-ICP-MS, an improvement of both the accuracy and the repeatability was observed for iron (certified value $211.6 \pm 6.5 \mathrm{mg} \mathrm{kg}^{-1} \mathrm{U}$ ): a $207.4 \pm 13.6 \mathrm{mg} \mathrm{kg}^{-1} \mathrm{U}$ was obtained with a $3 \%$ repeatability in medium resolution by SF-ICP-MS; compared to $189.1 \pm 23 \mathrm{mg} \mathrm{kg}^{-1} \mathrm{U}$ with a $6 \%$ repeatability at using of the Octopole Reaction System (ORS) of the Q-ICP-MS. The ${ }^{40} \mathrm{Ar}^{16} \mathrm{O}^{+}$interference was properly resolved on SF-ICP-MS in medium resolution and the measurement of iron could be easily performed at mass 56 . However, the measurement values are consistent with both ICP-MS.

\section{Conclusion}

This study presents a complete analytical procedure from the sample digestion to the concentration determination of $25 \mathrm{impu-}$ rities in a nuclear grade uranium oxide. After mineralization, the separation procedure allows for a total elimination of the uranium matrix and the subsequent impurities measurement. It limits the pollution and increases the productivity of the instrument. Moreover, this separative step improves the detection limits values compared to the ones obtained with a sample dilution step. The analytical results are in perfect agreement with the CRM values, except for six elements whose values are slightly underestimated, allowing us to validate our entire procedure.

The polyatomic interference $\left({ }^{40} \mathrm{Ar}^{16} \mathrm{O}^{+}\right)$, which hinders the analysis of iron $\left({ }^{56} \mathrm{Fe}^{+}\right)$at low level concentration, was significantly reduced following three different ways: cold plasma conditions, medium resolution and ORS mode.

In the standard mode, the SF-ICP-MS presented systematically a better sensitivity that allowed to reach lower concentration level than the Q-ICP-MS (44 vs. $215 \mathrm{ng} \mathrm{L}^{-1}$ at mass 57).

With cold plasma conditions, the iron measurement could be made at mass 56 as the formation of ${ }^{40} \mathrm{Ar}^{16} \mathrm{O}^{+}$was drastically reduced. Consequently, the Q-ICP-MS detection limit was improved to $15 \mathrm{ng} \mathrm{L}^{-1}$, compared to $215 \mathrm{ng} \mathrm{L}^{-1}$ at mass 57 in the standard mode. Q-ICP-MS showed also better results than the SF-ICP-MS (132 ng L ${ }^{-1}$ ).

The lowest detection limits with Q-ICP-MS were achieved using collision/reaction cell. Indeed, a $8 \mathrm{ng} \mathrm{L}^{-1}$ detection limits was obtained using $\mathrm{CH}_{4}$ as a reaction gas and $12 \mathrm{ng} \mathrm{L}^{-1}$ with He in a collision process, thus improving the detection limits by a 25 fold factor compare to the standard mode. Similarly, using medium resolution with the SF-ICP-MS allowed to properly reduce the $\mathrm{ArO}^{+}$interference and to measure iron at mass 56 with $10 \mathrm{ng} \mathrm{L}^{-1}$ detection limit. Finally, iron was measured with a good accuracy (less than $5 \%$ ) with He as collision gas and with the use of the medium resolution.

The interferences are significantly reduced with the use of the collision/reaction cell, but are not completely removed. Nevertheless, Q-ICP-MS, equipped with the latest generation of collision/reaction cell, have become a key technique for multielementary analysis at trace and ultra-trace levels: they are reasonable cost, relatively easy to use and with short time set-up.

Currently, isotopic dilution is investigated to overcome potential problem of separation yield and to improve the measurement accuracy. So far, it has been successfully tested on a round-robin test solution: for all of the seven elements of interest $(\mathrm{Ce}, \mathrm{Cu}, \mathrm{La}$, Mo, Th, Cd and Mn), results are in perfect agreement with the certified value and with an accuracy better than $5 \%$. In a near future, CRMs with lower certified concentration will be investigated to test the separation yield for elements from different groups.

\section{References}

[1] O.P. Oliveira Junior, J.E.S. Sarkis, J. Radioanal. Nucl. Chem. 254 (2002) 519-526526.

[2] K. Satyanarayana, S. Durani, J. Radioanal. Nucl. Chem. 285 (2010) 659-665.

[3] S. Burger, L.R. Riciputi, D.A. Bostick, J. Radioanal. Nucl. Chem. 274 (2007) 491-505.

[4] V.C. Adya, A. Sengupta, B.A. Dhawale, B. Rajeswari, S.K. Thulasidas, S.V. Godbole, J. Radioanal. Nucl. Chem. 291 (2012) 843-848.

[5] A. Sengupta, M.J. Kulkarni, S.V. Godbole, J. Radioanal. Nucl. Chem. 289 (2011) 961-965.

[6] M.G. Gonzalez, E.N. Ponzi, M.A. Laborde, N.O. Lemcoff, Rev. Latinoam. Ing. Quim. Quim. Apl.-Lat. Am. J. Chem. Eng. Appl. Chem. 13 (1983) 59-70.

[7] A. Inoue, T. Tsujino, Ind. Eng. Chem. Process Des. Dev. 23 (1984) 122-125.

[8] K. Chander, B.N. Patil, J.V. Kamat, N.B. Khedekar, R.B. Manolkar, S.G. Marathe, Nucl. Technol. 78 (1987) 69-74.

[9] E. Zimmer, E. Merz, J. Nucl. Mater. 124 (1984) 64-67.

[10] S.C. Smith, S.M. Peper, M. Douglas, K.L. Ziegelgruber, E.C. Finn, J. Radioanal. Nucl. Chem. 282 (2009) 617-621.

[11] Y. Asano, M. Kataoka, Y. Ikeda, S. Hasegawa, Y. Takashima, H. Tomiyasu, Prog. Nucl. Energy 29 (1995).

[12] E.H. Kim, D.S. Hwang, W.M. Choung, J.H. Park, J.H. Yoo, C.S. Choi, Radiochim. Acta 83 (1998) 147-151.

[13] M.D. Samsonov, C.M. Wai, S.C. Lee, Y. Kulyako, N.G. Smart, Chem. Commun. (2001) 1868-1869.

[14] Y. Zhao, J. Chen, Korean J. Chem. Eng. 26 (2009) 165-167.

[15] Y. Zhao, J. Chen, Radiochim. Acta 96 (2008) 467-471.

[16] S. Marin, S. Cornejo, C. Jara, N. Duran, Fresenius J. Anal. Chem. 355 (1996) 680-683. 
[17] S. Vijayalakshmi, R.K. Prabhu, T.R. Mahalingam, C.K. Mathews, J. Anal. At. Spectrom. 7 (1992) 565-569.

[18] M.A. Floyd, R.W. Morrow, R.B. Farrar, Spectrochim. Acta Part B-At. Spectrosc. 38 (1983) 303-308.

[19] E.A. Huff, Spectrochim. Acta Part B-At. Spectrosc. 42 (1987) 275-283.

[20] M. Shamsipur, Y. Yamini, P. Ashtari, A. Khanchi, M. Ghannadi-Marageh, Sep. Sci. Technol. 35 (2000) 1011-1019.

[21] V.M. Golik, S.V. Golik, S.A. Trepachev, N.V. Kuz'mina, J. Anal. Chem. 65 (2010) 1511-1516.

[22] F. Gueguen, A. Nonell, M. Granet, G. Favre, H. Isnard, F. Chartier, J. Anal. At. Spectrom. 25 (2010) 201-205.

[23] H. Isnard, M. Aubert, P. Blanchet, R. Brennetot, F. Chartier, V. Geertsen, F. Manuguerra, Spectrochim. Acta Part B-At. Spectrosc. 61 (2006) 150-156.

[24] K. Kehm, E.H. Hauri, C.M.O. Alexander, R.W. Carlson, Geochim. Cosmochim. Acta 67 (2003) 2879-2891.

[25] M. Segura, Y. Madrid, C. Camara, J. Anal. At. Spectrom. 18 (2003) 1103-1108.

[26] W. Castro, T. Trejos, B. Naes, J.R. Almirall, Anal. Bioanal. Chem. 392 (2008) 663-672.

[27] P.K. Appelblad, I. Rodushkin, D.C. Baxter, J. Anal. At. Spectrom. 15 (2000) 359-364.

[28] J.W. Ferguson, R.S. Houk, Spectrochim. Acta Part B—At. Spectrosc. 61 (2006) 905-915.

[29] G. Favre, R. Brennetot, F. Chartier, P. Vitorge, Int. J. Mass Spectrom. 265 (2007) $15-22$.

[30] J. Moureau, M. Granet, F. Chartier, G. Favre, H. Isnard, A. Nonell, J. Anal. At. Spectrom. 23 (2008) 1538-1544.

[31] H. Isnard, R. Brennetot, C. Caussignac, N. Caussignac, F. Chartier, Int. J. Mass Spectrom. 246 (2005) 66-73.
[32] R. Brennetot, L. Pierry, T. Atamyan, G. Favre, D. Vailhen, J. Anal. At. Spectrom. 23 (2008) 1350-1358.

[33] S.D. Tanner, V.I. Baranov, D.R. Bandura, Spectrochim. Acta Part B-At Spectrosc. 57 (2002) 1361-1452.

[34] M. Iglesias, N. Gilon, E. Poussel, J.M. Mermet, J. Anal. At. Spectrom. 17 (2002) 1240-1247.

[35] M. Niemela, P. Peramaki, H. Kola, J. Piispanen, Anal. Chim. Acta 493 (2003) 3-12.

[36] L. Balcaen, I. Geuens, L. Moens, F. Vanhaecke, Anal. Bioanal. Chem. 377 (2003) 1020-1025.

[37] G.K. Koyanagi, V.V. Lavrov, V. Baranov, D. Bandura, S. Tanner, J.W. McLaren, D.K. Bohme, Int. J. Mass Spectrom. 194 (2000) L1-L5.

[38] T. Arnold, J.N. Harvey, D.J. Weiss, Spectrochim. Acta Part B-At. Spectrosc. 63 (2008) 666-672.

[39] G.K. Koyanagi, V.I. Baranov, S.D. Tanner, D.K. Bohme, J. Anal. At. Spectrom. 15 (2000) 1207-1210.

[40] D.R. Bandura, V.I. Baranov, S.D. Tanner, Fresenius J. Anal. Chem. 370 (2001) 454-470.

[41] D.W. Koppenaal, G.C. Eiden, C.J. Barinaga, J. Anal. At. Spectrom. 19 (2004) 561-570.

[42] R.S. Houk, N. Praphairaksit, Spectrochim. Acta Part B-At. Spectrosc. 56 (2001) 1069-1096.

[43] L.S. Huang, K.C. Lin, Spectrochim. Acta Part B-At. Spectrosc. 56 (2001) 123-128.

[44] E. McCurdy, G. Woods, J. Anal. At. Spectrom. 19 (2004) 607-615.

[45] A. Shayesteh, V.V. Lavrov, G.K. Koyanagi, D.K. Bohme, J. Phys. Chem. A 113 (2009) 5602-5611. 